\title{
BIBLIOGRAPHIES
}

\section{WALT WHITMAN BIBLIOGRAPHIES: \\ A Chronological Listing, 1897-1982}

Fifteen years ago, in volume 25, number 5, of the Bulletin of Bibliography, James T. F. Tanner published a chronological checklist of bibliographies on Walt Whitman. Spanning the years from 1902 through 1964, this list cited sixty-eight books, chapters in books, catalogues, pamphlets, and articles. Since its entries varied widely in length and importance, it gave the appearance of being comprehensive in scope. It was not. Recent research on Whitman has turned up publications which should be added to Tanner's list. It has also disclosed the many bibliographical resources printed in the past two decades. The following bibliography, therefore, both augments and updates Tanner's compilation. The result is a survey which extends from 1897 through 1982. Coupled with Tanner's checklist, it represents a complete, or at least reasonably complete, listing of all of the bibliographies on Whitman's life and work.

\section{Additions to the fames T. F. Tanner Checklist:}

Foley, P. K. "Whitman, Walt[er]. 1819-1892." In American Authors, 1795-1895: A Bibliography of First and Notable Editions Chronologically Arranged with Notes. Boston: Printed for Subscribers, 1897, pp. 307-310.

Anon. "A Bibliography of Walt Whitman." Bookman, 6 (1897), 81-82.

North, Ernest Dressel. "Notes on Rare Books." Book Buyer, 18 (1899), 228.

Platt, Isaac Hull. "Bibliography." In Walt Whitman. Beacon Biographies of Eminent Americans. Boston: Small, Maynard \& Co., 1904, pp. 141-147.

Trimble, W. H. "Appendix No. II: Bibliography." In Walt Whitman and Leaves of Grass: An Introduction. London: Watts \& Co., 1905, pp. 92-100.

- Catalogue of a Collection of Walt Whitman Literature, Compiled by the Owner. St. Leonards, Otago, New Zealand: "Concord," 1912. 36 pp.

Montolíu y de Togores, Cipriano, Marqués de. "Bibliografia." In Walt Whitman, l'Home is sa Tasca. Barcelona: Societat Catalana d'edicions, 1913, pp. 197-203.

Jones, P. M. "Whitman in France: A List of Translations from, and Studies etc. on Whitman Published in France before 1909." Modern Language Review, 10 (1915), 25-27.

Price, Lawrence Marsen. "English > German Literary Influences: Bibliography." University of California Publications in Modern Philology, 9 (1919), 102-103.

Anon. "Walt Whitman: A Bibliographical Survey." Bulletin of the Brooklyn Public Library, 11 (1919), 153-166. 
Breslow, M. M. “American First Editions. No. 38. Walt Whitman 1819-1892." Publishers' Weekly, 103 (30 June 1923), 1929-1930.

Chuykovskiĭ, Korneĭ Ivanovich. "Predislovie." In Uolt Uitmén i ego "List iâ Travy." Izd. 6., dop. Moskva, gos, izd-vo, 1923, pp. 5-9.

Kennedy, William Sloane. "A Bibliography of Walt Whitman's Writings" and "Index to Certain Whitman Articles in the 'Conservator.'" In The Fight of a Book for the World: A Companion Volume to Leaves of Grass. West Yarmouth, Mass.: Stonecroft Press, 1926, pp. 237-272, 273-286.

Catel, Jean. "Bibliographie." In Walt Whitman: La Naissance du Poète. Paris: Les Éditions Rieder, 1929, pp. 471-479.

- "Bibliographie." In Rythme et langage dans la 1re édition des "Leaves of Grass" (1855). Paris: Les Éditions Rieder, 1930, pp. 188-195.

Barrus, Clara. "Bibliography of Burroughs on Whitman." In Whitman and Burroughs: Comrades. Boston: Houghton Mifflin Company, 1931, pp. 377-379.

Bucke, Richard Maurice. Catalogue of Important Letters, Manuscripts and Books By or Relating to Walt Whitman. . . London: Printed by Kitchen and Barratt, Ltd., 1935. $31 \mathrm{pp}$.

Englekirk, John E. "Notes on Whitman in Spanish America." Hispanic Review, 6 (1938), 133-138.

Arvin, Newton. "Bibliography." In Whitman. New York: Macmillan Co., 1938, pp. 297-312.

McCusker, Honor. "Leaves of Grass: First Editions and Manuscripts in the Whitman Collection." More Books: The Bulletin of the Boston Public Library, 12 (1938), 179-192.

Chukovskil̆, Kornel. "Uolt Uitmen v SSSR: Bibliograficheskie zametki" [Walt Whitman in the U.S.S.R.: Collected Bibliography]. Internatsionalnaya Literatura, nos. 1-2 (1942), 204-206.

Johnson, Merle D. "Walt[er] Whitman." In Merle fohnson's American First Editions. 4th ed. Revised and enlarged by Jacob Blanck. New York: R. R. Bowker Co., 1942, pp. 528-532.

Englekirk, John E. "Primera Parte: Literatura (Biografia, Cuento, Drama, Ensayo, Novela, Poesía, Viajes)." In Bibliografía de Obras Norteamericanas en Traduccion Española. Mexico: n.p., 1944, pp. 72-73.

. "Bibliografia de Obras Norteamericanas em Tradução Portuguesa." In $A$ Literature Norteamericana no Brazil. Mexico: n.p., 1950, pp. 132-135.

Saunders, Henry S. Whitman in Fiction. Toronto: Henry S. Saunders, 1950. 6 pp. Whitman Music List. Toronto: Henry S. Saunders, 1950. 26 pp.

Faner, Robert D. "Bibliography." In Walt Whitman and Opera. Philadelphia: University of Pennsylvania Press, 1951, pp. 237-244. 
Beaver, Joseph. "Bibliography." In Walt Whitman-Poet of Science. New York: King's Crown Press, 1951, pp. 171-174.

Asselineau, Roger. "Bibliographie." In L'Évolution de Walt Whitman: Après la première édition des Feuilles d'herbe. Paris: Marcel Didier, 1954, pp. 528-545.

31-40. "État présent des études Whitmaniennes." Études Anglaises, 11 (1958),

Ludwig, Richard M. et al. "Walt(er) Whitman." In Literary History of the United States: Bibliography Supplement. Ed. Robert E. Spiller et al. New York: Macmillan Co., 1959, pp. 203-207.

White, William. "Walt Whitman's Short Stories: Two Addenda." Papers of the Bibliographical Society of America, 54 (1960), 126.

Anon. "Notes on Recent and Forthcoming Books." Long-Islander, 25 May 1961, Section III, p. 1.

White, William. "Whitman in Paperback." American Book Collector, 11(1961), 28-30.

Meliado, Mariolina. "La Fortuna Di Walt Whitman in Italia." Studi Americani (Rome), 7 (1961), 43-76.

Tanselle, G. Thomas. "Whitman's Short Stories: Another Reprint." Papers of the Bibliographical Society of America, 56 (1962), 115.

Broderick, John C. "Selected Bibliography for Further Reading." In Whitman the Poet: Materials for Study. Ed. John C. Broderick. Belmont, Calif.: Wadsworth Publishing Co., 1962, pp. 171-186.

Asselineau, Roger. "Selected Bibliography." In The Evolution of Walt Whitman: The Creation of a Book. Cambridge, Mass.: Harvard University Press, Belknap Press, 1962, pp. 261-271.

Mathews, J. Chesley. "Bibliographical Supplement: Whitman.” In Eight American Authors: A Review of Research and Criticism. Ed. Floyd Stovall. New York: Norton \& Co., 1963, pp. 445-451.

White, William. "Addenda to Whitman's Short Stories." Papers of the Bibliographical Society of America, 57 (1963), 221-222.

Ishii, M. and T. Shinagawa. "Bibliography of Whitman in Japan." Hikaku Bungaku: Fournal of Comparative Literature, 7 (1964), 77-110.

Libman, V. A. "Bibliography: Critical Works on American Literature in Russia ... Walt Whitman." In Problemy istorii literatury SShA [Problems in the History of Literature of the U.S.A.]. Ed. G. P. Zlobin. Moscow: Akademiia Nauk SSSR, 1964, pp. 460-463. 
Bradley, E. Sculley. "Whitman." In American Literary Scholarship: An Annual/1963. Ed. James Woodress. Durham, N.C.: Duke University Press, 1965, pp. 41-52.

Hall, Susan Corwin. "Walt Whitman." In Hawthorne to Hemingway: An Annotated Bibliography of Books from 1945 to 1963 About Nine American Writers. Ed. Robert H. Woodward. New York: Garrett Publishing Co., 1965, pp. 16-25.

White, William. "Yearly Report to the Stockholders. . . ." Long-Islander, 3 June 1965, Section II, pp. 4-5.

Shinagawa, T. "Supplement to the Bibliography of Walt Whitman in Japan." Hikaku Bungaku: Fournal of Comparative Literature, 8 (1965), 104-111.

Reiss, Edmund. "Recent Scholarship on Whitman and Dickinson." In The Teacher and American Literature: Papers Presented at the 1964 Convention of the National Council of Teachers of English. Ed. Lewis Leary. Champaign, Ill.: National Council of Teachers of English, 1965, pp. 115-127.

Miller, F. DeWolfe. "Whitman Bibliography in Russia." Walt Whitman Review, 11 (1965), 77-79.

White, William. "Whitman: A Current Bibliography." Walt Whitman Review, 11 (1965), 21-23, 56-57, 80-81, 104-105.

Doyle, P. A. "The Walt Whitman Exhibit at Nassau Community College Library." Library Newsletter (Nassau Community College, Garden City, N.Y.), 1 (1966), $1-4$.

Grier, Edward F. "Whitman." In American Literary Scholarship: An Annual/1964. Ed. James Woodress. Durham, N.C.: Duke University Press, 1966, pp. 43-49.

Woodbridge, Hensley C. "Walt Whitman: Additional Bibliography in Spanish." Walt Whitman Review, 12 (1966), 70-71.

White, William. "Whitman: A Current Bibliography." Walt Whitman Review, 12 (1966), 22-23, 45-46, 72-73, 102-103.

Grier, Edward F. "Whitman." In American Literary Scholarship: An Annual/1965. Ed. James Woodress. Durham, N.C.: Duke University Press, 1967, pp. 45-56.

White, William. "Whitman: A Current Bibliography." Walt Whitman Review, 13 (1967), 33-34, 68-69, 102-103, 128-129.

Tanner, James T. F. "Walt Whitman Bibliographies: A Chronological Listing, 1902-1964." Bulletin of Bibliography, 25 (1968), 131-132.

Woodress, James. "Whitman, Walt." In Dissertations in American Literature, 18911966. Newly Revised and Enlarged with the Assistance of Marian Koritz. Durham, N.C.: Duke University Press, 1968, pp. [90-92].

Grier, Edward F. "Walt Whitman." In American Literary Scholarship: An Annual/ 1966. Ed. James Woodress. Durham, N.C.: Duke University Press, 1968, pp. 40-47. 
White, William. "Walt Whitman's Journalism: A Bibliography." Walt Whitman Review, 14 (1968), 67-141.

Tanner, James T. F. Walt Whitman: A Supplementary Bibliography: 1961-1967. Kent, Ohio: Kent State University Press, 1968.59 pp.

White, William. "Whitman: A Current Bibliography." Walt Whitman Review, 14 (1968), 30-31, 62-63, 178-79.

Libman, Valentina A. "Whitman Walt." In Russian Studies of American Literature: A Bibliography. Trans. Robert V. Allen, ed. Clarence Gohdes. Chapel Hill: University of North Carolina Press, 1969, pp. 201-208.

Grier, Edward F. "Whitman and Dickinson." In American Literary Scholarship: An Annual/1967. Ed. James Woodress. Durham, N.C.: Duke University Press, 1969, pp. $48-55$.

White, William. Walt Whitman's fournalism: A Bibliography. Detroit: Wayne State University Press, 1969. 73 pp.

Sadoya, Shigenobu. "A Bibliography of Walt Whitman in Japan from 1892 to 1968." In Walt Whitman in fapan: His Influence in Modern Fapan. Bulletin no. 9. Fukuoka, Japan: Research Institute, Seinan Gakuin University, 1969, pp. 9-20.

White, William. "Whitman: A Current Bibliography." Walt Whitman Revierv, 15 (1969), 62-63, 126-127, 196-197, 253-255.

Leary, Lewis, comp. "Whitman, Walt." In Articles on American Literature 1950-1967. Compiled with the assistance of Carolyn Bartholet and Catherine Roth. Durham, N.C.: Duke University Press, 1970, pp. 550-572.

White, William. "The Whitman Industry Pays Dividends." Long-Islander, 28 May 1970, Section I, pp. 9, 12.

Nilon, Charles H. "Whitman, Walt." In Bibliography of Bibliographies in American Literature. New York and London: R. R. Bowker Co., 1970, pp. 159-165.

Grier, Edward F. "Whitman and Dickinson." In American Literary Scholarship: An Annual/1968. Ed. J. Albert Robbins. Durham, N.C.: Duke University Press, 1970, pp. 50-65.

White, William. "Whitman: A Current Bibliography." Walt Whitman Review, 16 (1970), 29-30, 61-63, 94-95, 125-127.

Asselineau, Roger. "Walt Whitman." In Eight American Authors: A Review of Research and Criticism. Ed. James Woodress. Rev. Ed. New York: W: W. Norton \& Co., 1971, pp. 225-272.

White, William. "Whitman and the MLA Bibliography: Addenda, 1969." Serif, 8 (1971), 18-20. 2, no. 1 (1971), 10. 
Slote, Bernice. "Whitman and Dickinson." In American Literary Scholarship: An Annual/1969. Ed. J. Albert Robbins. Durham, N.C.: Duke University Press, 1971, pp. 56-76.

Clark, Harry Hayden. "Walt Whitman (1819-1892)." In American Literature: Poe Through Garland. Goldentree Bibliographies in Language and Literature. New York: Appleton-Century-Crofts/Meredith Corp., 1971, pp. 89-97.

White, William. "Whitman: A Current Bibliography." Walt Whitman Review, 17 (1971), 29-31, 68-69, 103-105, 143-145.

Slote, Bernice. "Whitman and Dickinson." In American Literary Scholarship: An Annual/1970. Ed. J. Albert Robbins. Durham, N.C.: Duke University Press, 1972, pp. 55-76.

Chanover, E. Pierre. "Walt Whitman: A Psychological and Psychoanalytic Bibliography." Psychoanalytic Review, 59 (1972), 467-474.

White, William. "Whitman: A Current Bibliography." Walt Whitman Review, 18 (1972), 34-35, 70-71, 106-108, 140-141.

Howard, Patsy C., comp. "Walt Whitman." In Theses in American Literature 18961971. Ann Arbor, Mich.: Pierian Press, 1973, pp. 238-244.

Slote, Bernice. "Whitman and Dickinson." In American Literary Scholarship: An Annual/1971. Ed. J. Albert Robbins. Durham, N.C.: Duke University Press, 1973, pp. 59-74.

White, William. "Whitman: A Current Bibliography." Walt Whitman Review, 19 (1973), 32-33, 75-77, 122-123, 170-171.

Slote, Bernice. "Whitman and Dickinson." In American Literary Scholarship: An Annual/1972. Ed. J. Albert Robbins. Durham, N.C.: Duke University Press, 1974, pp. 59-72.

White, William. "Walt Whitman's Poetry in Periodicals: A Bibliography." Serif, 11 (1974), 31-38.

_. "Whitman: A Current Bibliography."Walt Whitman Review, 20 (1974), 3537, 74-75, 116-117, 156-157.

Allen, Gay Wilson. "Selected Bibliography." In The New Walt Whitman Handbook. New York: New York University Press, 1975, pp. 369-410.

Slote, Bernice. "Whitman and Dickinson." In American Literary Scholarship: An Annual/1973. Ed. James Woodress. Durham, N.C.: Duke University Press, 1975, pp. 85-98.

Randle, Betty, ed. Catalogue of the Collection of Walt Whitman Literature Presented to the Dunedin Public Library by W. H. Trimble. Dunedin, New Zealand: Dunedin Public Library, 1975. 68 pp.

White, William. "Whitman: A Current Bibliography." Walt Whitman Review, 21 (1975), 42-43, 80-81, 130-131, 166-167. 
Babić, Ljiljana. "Walt Whitman in Yugoslavia." Acta Neophilologica, 9 (1976), 9-58.

Schaper, Monika. Walt Whitman's "Leaves of Grass" in deutschen Übersetzungen: Eine rezeptionsgeschichtliche Untersuchung. Frankfurt/M: Peter Lang; Bern: Herbert Lang, 1976. 202 pp.

Slote, Bernice. "Whitman and Dickinson." In American Literary Scholarship: An Anual/1974. Ed. James Woodress. Durham, N.C.: Duke University Press, 1976, pp. 61-74.

Leary, Lewis. "Walt Whitman (1819-1892)." In American Literature: A Study and Research Guide. With the collaboration of John Auchard. New York: St. Martin's Press, 1976, pp. 132-134.

White, William. "Whitman: A Current Bibliography." Walt Whitman Review, 22 (1976), 46-47, 90-91, 132-133, 170-172.

Fisher, Marvin, and Willis J. Buckingham. "Whitman and Dickinson." In American Literary Scholarship: An Annual/1975. Ed. James Woodress, Durham, N.C.: Duke University Press, 1977, pp. 83-102.

Anon. "Whitman, Walter (1819-1892)." In Literary Writings in America: A Bibliography. Vol. 8. Ed. Edward H. O'Neill et al. Millwood, N.Y.: KTO Press, 1977, pp. 10405-10433.

White, William. "Whitman: A Current Bibliography." Walt Whitman Review, 23 (1977), 54-55, 97-99, 143, 177-178.

Francis, Gloria A., and Artem Lozynsky. Whitman at Auction, 1899-1972. A Bruccoli Clark Book. Detroit: Gale Research Company, 1978. 471 pp.

Fisher, Marvin, and Willis J. Buckingham. "Whitman and Dickinson." In American Literary Scholarship: An Annual/1976. Ed. James Woodress. Durham, N.C.: Duke University Press, 1978, pp. 61-78.

White, William. "Whitman: A Current Bibliography." Walt Whitman Review, 24 (1978), 39-41, 90-91, 132-133, 167-168.

Monteiro, George. "Addenda to the Bibliographies of Cather, Conrad, De Forest, Dreiser, Forster, Hardy, Hawthorne, London, Norris, Poe, Wharton, and Whitman." Papers of the Bibliographical Society of America, 73 (1979), 478-481.

Buckingham, Willis J. "Whitman and Dickinson." In American Literary Scholarship: An Annual/1977. Ed. James Woodress. Durham, N.C.: Duke University Press, 1979, pp. 65-85.

White, William. "Whitman: A Current Bibliography." Walt Whitman Review, 25 (1979), 34, 80-83, 125-127, 180-181.

Rubino, Anne L. In Re Walt Whitman: An Exhibition of Selected Writings. Hempstead, N.Y.: Hofstra University Library, 1980. [44] pp. 
Boswell, Jeanetta. Walt Whitman and the Critics: A Checklist of Criticism, 19001978. Scarecrow Author Bibliographies, No. 51. Metuchen, N.J.: Scarecrow Press, 1980. 257 pp.

French, Roberts W. "Whitman as Poetic Subject." Walt Whitman Review, 26 (1980), 69-70.

Buckingham, Willis J. "Whitman and Dickinson." In American Literary Scholarship: An Annual/1978. Ed. J. Albert Robbins. Durham, N.C.: Duke University Press, 1980, pp. 59-78.

Erkkila, Betsy. "Chronological List of French Criticism of Whitman Since 1861" and "Chronological List of French Translations of Whitman Since 1886." In Walt Whitman Among the French: Poet and Myth. Princeton, N.J.: Princeton University Press, 1980, pp. 239-250, 251-255.

Fontana, Nicholas. "Bibliographical and Critical Bibliography: Whitman Birthplace Library." West Hills Review: A Walt Whitman fournal, 2 (1980), 15-19.

White, William. "Whitman: A Current Bibliography." Walt Whitman Review, 26 (1980), 37-39, 78-79, 123-125, 163-164.

Folsom, Ed. "The Poets Respond: A Bibliographic Chronology." In Walt Whitman: The Measure of His Song. Eds. Jim Perlman, Ed Folsom, and Dan Campion. Minneapolis: Holy Cow! Press, 1981, pp. 359-381.

Buckingham, Willis J. "Whitman and Dickinson." In American Literary Scholarship: An Annual/1979. Ed. James Woodress. Durham, N.C.: Duke University Press, 1981, pp. 61-79.

Giantvalley, Scott. Walt Whitman, 1838-1939: A Reference Guide. Boston: G. K. Hall and Company, 1981. 465 pp.

White, William. "Whitman: A Current Bibliography." Walt Whitman Review, 27 (1981), 46-47, 91, 138-139, 174-175.

Vondrasek, Betsy. "Music at the Whitman House: Bibliography." West Hills Review: A Walt Whitman fournal, 3 (1982), 63-68.

Kummings, Donald D. Walt Whitman, 1940-1975: A Reference Guide. Boston: G. K. Hall and Company, 1982. 264 pp.

Loving, Jerome. "Whitman and Dickinson." In American Literary Scholarship: An Annual/1980. Ed. J. Albert Robbins. Durham, N.C.: Duke University Press, 1982, pp. 67-88.

French, Roberts W., and William White. "Whitman: A Current Bibliography." Walt Whitman Review, 28 (1982), 37-38, 81-83, 106-108. 